\title{
Rally for Normative Demands and Solidarity of Workers
}

Komunitas: International Journal of Indonesian Society and Culture 9(2) (2017): 283-291

DOI:10.15294/komunitas.v9i2 5480

(C) 2017 Semarang State University, Indonesia p-ISSN 2086 - 5465 | e-ISSN 2460-7320 http://journal.unnes.ac.id/nju/index.php/komunitas

UNNES JOURNALS

\author{
Ari Pradhanawati ${ }^{1}$ \\ 1Social and Political Science Faculty, Universitas Diponegoro, Indonesia
}

Received: March 2016; Accepted: July 2017; Published: September 2017

\begin{abstract}
This research is initiated by an interesting fact that there are still many labor strikes and rallies in Indonesia. The purpose of this study is to determine: the influence of normative demands and solidarity together on job dissatisfaction of workers. This research is intended as explanatory research. Sampling method used in this research is accidental sampling. The sample consists of 100 workers/laborers who joined rallies on May 1,2014 . The results show on the indicator the amount of City Minimum Wage Rates in normative demands variable, respondents believe the amount of wages earned are still not in accordance with the provisions of the minimum wage set by the government. Participation of workers in the fight for economic security must be done in various ways including demonstrations, based on solidarity between workers in order to put pressure on policy makers with regard to labor issues. In conclusion, good normative demands in accordance with the provisions of the agreement and the strong solidarity between workers will reduce dissatisfaction. Suggestions are made on normative demands variable; review should be made on the amount of the city minimum wage rates; leave entitlements, workers social security and dismissal policies should be in compliance with the current government policy.
\end{abstract}

\section{Keywords}

normative demands; solidarity; labor job dissatisfaction

\section{INTRODUCTION}

Labor Day 1 May 2014 in Indonesia is the beginning of labor struggle when there is something new that the day is a national holiday. Laborers are free to take to the streets to protest their rights as laborers. The demand concerns the issue of wages which is still considered low, which often leads to conflict between workers and employers. Whereas according to Kurbetti (2014), if industrial relation is friendly, harmoniously and collaboratively built among employees, between employees and employers, it can eliminate conflict and can actually increase coopera- tion.

The explanation of Law No. 13/2003 states that if industrial relation disputes do not reach the point of solution, workers are entitled to strike. The number of strikes and demonstrations in Indonesia is still very high. By the year 2013 until the middle of the year, there have been 77 times overall with the total number of workers involved reaching 19,687 people, and 97,989 of working hours lost (Ministry of Manpower and

\footnotetext{
Corresponding author

JI. Prof. H. Soedarto, Tembalang, Semarang, Central Java, 50139, Indonesia

Email

pradhanawatiari@rocketmail.com
} 
Transmigration 2013). Working strikes and labor protests cause a high lost of working hours, cause business loss and make potential investors hesitate to invest in Indonesia. This is reinforced by the results of research by Jiang (2009) stating that job dissatisfaction causes decreased turnover due to the high turnover rate of labor so that the quality is low. On the other hand, dissatisfaction arises because there are employees who are not satisfied with the work situation so they have attitude to unionize (Sarkar 2012; Vangel 2011; Chan et al. 2010; Ford 2013; Juliawan 2011; Thomas \& Sudhakumar 2012, 2014). It is in line with Farber (1990) and Stuart (1984) stating that employees who are not satisfied with the work situation will have the attitude to unionize.

Working strikes are closely related to labor solidarity in an effort to improve the conditions of the workers from job dissatisfaction. The concept of labor solidarity is the relationship between individuals and/or groups formed on the basis of moral feelings and beliefs shared and reinforced by shared emotional experience.

Biezenski (1996) explains that solidarity is closely related to leadership style in eliminating conflict, because according to Oshagbemi (1997) and SANDERS (2006), there is a relationship between leadership style and employees based on cohesiveness and behavior of horizontal and vertical solidarity. Furthermore, Tinley (2014) reinforces that strong cohesion and solidarity among women's groups can increase income opportunities for marginalized rural women from micro-enterprise policy projects. According to Sutopo's research results in the Komunitas Journal, Vol. September 2, 2013, the low educational qualifications of women can result in low wages that they receive because of their position as workers only. Thus Sammut \& Gillespie (2011) emphasizes that the problem of solidarity arises from a heterogeneous society.

In this regard, Hogg and Abrams (1990, p.35) explain that labor participation in demonstrations is a strategy that workers create in collectively solving problems. Thus the work strike/demonstration occur- red because of the disharmony of working relations between workers and employers. For example, the demands of the workers are less responded or not met so that it can lead to conflict. The condition is in line with Tiberius \& Hall (2010) stating that the demands of the protesters are often the main problem because normative demands contribute to job satisfaction which ultimately will improve their welfare.

Disputes in industrial relations between workers and employers are generally due to lack of coordination and good relations or lack of flexibility and harmony between them. It requires a commitment from both so that disputes or conflicts can be eliminated in such a way. Conditions that occur in Indonesia show that almost every time industrial relations deteriorate from year to year because of the problem of labor's wages that is relatively still below the minimum standards set by the government. Semarang city's minimum wage $(U M K)$ in 2014 is Rp. $1,423,500,-$ the highest among 35 regencies/ cities in Central Java Province, but the lowest category among the four provinces, that is, Surabaya City's (East Java Province) of Rp. 2.200.00o, -. Bandung city's (West Java Province) of Rp. 2.00o.ooo, - and Jakarta City's (DKI Province) of Rp. 2.441.301,74, -. The amount of city minimum wagse is determined by the commitment of the mayor or the governor and the local wage.

The relatively low city minimum wage is considered inadequate to satisfy the standards of physical, non-physical and social living needs cosisting of 60 kinds ranging from clothing, food and shelter. The condition causes the workers to experience dissatisfaction. Because the demands on wages are often not met by employers, they do work strike. This is in line with research findings of Sarfraz, et al (2010) stating that low wages will have a positive impact on employees on work dissatisfaction.

The results of previous research by Tyagita, A. (2011) explain that the struggle of the workers to uphold normative rights can not necessarily be implemented, because it requires a real support from the organization as a media to strengthen the position 
of workers in trade unions, so that workers' normative rights can be protected through the establishment of collective labor agreements between trade unions and employers.

The results of previous research by Setyawan, H., \& Affandi, MA (2017) explain that the determination of wages uses and combines two strategies, namely through mass movement by pressing the government and wage council and doing advocation, that is, strengthen mass movement to determine the amount of wage increase.

The existing researches focused more on wage issues and their impacts, while this study looks at the issue of labor wages from another side, namely the influence of normative demands, solidarity and both together against the dissatisfaction of labor.

The amount of city minimum wage actually can be a comparative advantage of workers in Indonesia because it is in the category of cheap when compared to outside Indonesia where wages are much more expensive. However, city minimum wages for labors in Indonesia in general and Semarang and its surrounding in particular is still relatively low and do not meet the standard of life necessities.

\section{RESEARCH METHOD}

The variables studied were normative demands $\left(\mathrm{X}_{1}\right)$, solidarity $\left(\mathrm{X}_{2}\right)$ and labor dissatisfaction $(\mathrm{Y})$ and described in Table 1.

The type of this research is explanatory research using accidental sampling that is laborers who follow Labor Day Celebration of 1 May 2014 in Semarang City. The sample size is 100 people. Measurement scale uses Likert Scale. Data collection techniques uses questionnaires. Data analysis uses average score, simple linear regression and multiple linear regression.

\section{RESULTS AND DISCUSSION}

Table 2 describes the characteristics of the respondents, consisting mostly of women $(62 \%)$; men (38\%) with the age of $18-25$ years $(24 \%)$, the marital status of $80 \%$ married, some of them are domiciled in Demak Regency (42\%) and Semarang City (34\%), working period of between 1 - 5 years $(38 \%)$ and $90 \%$ of workers are member of KSPN union.

Table 3 Explain the results of the study by using the average score of indicators of the variables of normative demands, solidarity and workers' job dissatisfaction.

Table 3 describes the variables of normative demands: (1) the size of MSEs contributes to the indicator average of 3.51; (2) workers' leave with the indicator average of 4.06; (3) social security get the indicator average of 4.16 and (4) dismissal has the indicator average of 3.96. While the average of all indicators is 3.92 with a total score of 5537 and the total frequency of 1400 . The average score of normative demands variable is 3.92 when compared to the range of the score $1-5$, then the results obtained is in the high category, it shows that the average of normative demands has been good but the Minimum City Wage is still relatively low.

Solidarity variable is influenced by: (1) concern gives the indicator average of 4.21; (2) giving each other has the indicator average of 4.12 and (3) voluntary favors contributed to the indicator average of 3.97. While the average of all indicators is 4.01 with a total score of 6148 and the total frequency

Table 1. Research Variable and Indicator

\begin{tabular}{|c|c|c|c|}
\hline Symbol & Name of Variable & $\begin{array}{l}\text { Type of } \\
\text { Variable }\end{array}$ & Indicator \\
\hline$X_{1}$ & $\begin{array}{l}\text { Normative De- } \\
\text { mands }\end{array}$ & Independent & $\begin{array}{l}\text { City Minimum Wages; Workers' Leave; Workers' } \\
\text { Social Security; Dismissal Policy }\end{array}$ \\
\hline$X_{2}$ & Solidarity & Independent & Concern; Give each other; Voluntary Favors \\
\hline Y & $\begin{array}{l}\text { Workers' Job Dis- } \\
\text { satisfaction }\end{array}$ & Dependent & $\begin{array}{l}\text { Forms of Workers' Job Dissatisfaction; Problems } \\
\text { That Are the Source of Workers' Job Dissatisfaction; } \\
\text { How to Deliver Workers' Job Dissatisfaction }\end{array}$ \\
\hline
\end{tabular}


Table 2. Characteristics of The Respondents

\begin{tabular}{|c|c|c|}
\hline Characteristics of The Respondents & Amount & Proportion (\%) \\
\hline Male & 38 & 38 \\
\hline Female & 62 & 62 \\
\hline Amount & 100 & 100 \\
\hline Aged $<24$ years old & 24 & 24 \\
\hline $25-29$ years old & 21 & 21 \\
\hline 30-34 years old & 21 & 21 \\
\hline $35-39$ years old & 20 & 20 \\
\hline $40-44$ years old & 6 & 6 \\
\hline $45-49$ years old & 6 & 6 \\
\hline$>50$ years old & 2 & 2 \\
\hline Amount & 100 & 100 \\
\hline Married & 80 & 80 \\
\hline Unmarried & 19 & 19 \\
\hline Widow/widower & 1 & 1 \\
\hline Amount & 100 & 100 \\
\hline No Elementary School Certificate & 1 & 1 \\
\hline Having Elementary School Certificate & 7 & 7 \\
\hline Having Junior High School Certificate & 19 & 19 \\
\hline Having Senior High School Certificate & 73 & 73 \\
\hline Amount & 100 & 100 \\
\hline Dimiciled in Demak & 42 & 42 \\
\hline Kendal & 1 & 1 \\
\hline Pati & 1 & 1 \\
\hline Purwodadi & 15 & 15 \\
\hline Purwokerto & 2 & 2 \\
\hline Salatiga & 1 & 1 \\
\hline Semarang & 34 & 34 \\
\hline Solo & 1 & 1 \\
\hline Temanggung & 1 & 1 \\
\hline Ungaran & 2 & 2 \\
\hline Amount & 100 & 100 \\
\hline Years of Services 1- 5 years & 38 & 38 \\
\hline 6-10 years & 22 & 22 \\
\hline 11-15 years & 10 & 10 \\
\hline 16-21 years & 10 & 10 \\
\hline$>22$ years & 20 & 20 \\
\hline Amount & 100 & 100 \\
\hline Members of KSPN Union & 91 & 91 \\
\hline KSPI & 2 & 2 \\
\hline Others & 7 & 7 \\
\hline Total & 100 & 100 \\
\hline
\end{tabular}

Source: Processed Primary Data, 2014 
Table 3. Table of The Average Score of Indicators

\begin{tabular}{|c|c|c|c|c|}
\hline Variable \& Indicator & $\begin{array}{l}\text { Indicator } \\
\text { Average }\end{array}$ & $\begin{array}{l}\text { Total } \\
\text { Score }\end{array}$ & $\begin{array}{l}\text { Total Fre- } \\
\text { quency }\end{array}$ & $\begin{array}{c}\text { The Average of All } \\
\text { Indicators } \\
\text { (Total Score : To- } \\
\text { tal Frequency) }\end{array}$ \\
\hline \multicolumn{5}{|l|}{ Normative Demands $\left(\mathrm{X}_{1}\right)$} \\
\hline City Minimum Wages & 3,51 & \multirow{4}{*}{5537} & \multirow{4}{*}{1400} & \multirow{4}{*}{3,92} \\
\hline Workers' Leave & 4,06 & & & \\
\hline Workers' Social Security & 4,16 & & & \\
\hline Dismissal Policy & 3,96 & & & \\
\hline \multicolumn{5}{|l|}{ Solidarity $\left(\mathrm{X}_{\mathbf{z}}\right)$} \\
\hline Concern & 4,21 & \multirow{3}{*}{6148} & \multirow{3}{*}{1500} & \multirow{3}{*}{4,01} \\
\hline Give Each Other & 4,12 & & & \\
\hline Voluntary Favors & 3,97 & & & \\
\hline \multicolumn{5}{|l|}{$\begin{array}{l}\text { Workers' Job Dissatisfaction } \\
\text { (Y) }\end{array}$} \\
\hline $\begin{array}{l}\text { Forms of Workers' Job Dissat- } \\
\text { isfaction }\end{array}$ & 3,89 & \multirow{3}{*}{5784} & \multirow{3}{*}{1500} & \multirow{3}{*}{3,86} \\
\hline $\begin{array}{l}\text { Problems That Are the Source } \\
\text { of Workers' Job Dissatisfaction }\end{array}$ & 3,90 & & & \\
\hline $\begin{array}{l}\text { How to Deliver Workers' Job } \\
\text { Dissatisfaction }\end{array}$ & 3,77 & & & \\
\hline
\end{tabular}

Source: Processed Primary Data, 2014

Table 4. Regression Analysis That Identifies the Effects of Normative Demands and Solidarity on Workers' Job Dissatisfaction

\begin{tabular}{|c|c|c|c|}
\hline Variable & $\begin{array}{l}\text { Correlation } \\
\text { Coefficient (r) }\end{array}$ & $\begin{array}{l}\text { Determination } \\
\text { Coefficient }\left(\mathbf{R}^{2}\right)\end{array}$ & Conclusion \\
\hline $\begin{array}{l}\text { Normative Demands } \\
(-0,240) \rightarrow \text { Workers' Job Dissatis- } \\
\text { faction }(47,718)\end{array}$ & 0,493 & 0,153 & $\begin{array}{l}\text { t count }-5,332<\mathrm{t} \text { ta- } \\
\text { ble-1,9845 } \\
\text { Significant }\end{array}$ \\
\hline $\begin{array}{l}\text { Solidarity }(0,331) \rightarrow \text { Workers' Job } \\
\text { Dissatisfaction }(41,214)\end{array}$ & 0,524 & 0,280 & $\begin{array}{l}\text { t count } 4,336>t \text { table } \\
1,9845 \\
\text { Significant }\end{array}$ \\
\hline $\begin{array}{l}\text { Normative Demands }(-0,202) \\
\text { and Solidarity }(0,331) \rightarrow \text { Work- } \\
\text { ers' Job Dissatisfaction }(41,281)\end{array}$ & 0,427 & 0,380 & $\begin{array}{l}\text { F count 10,625> F table } \\
\text { 3,0902 } \\
\text { Significant }\end{array}$ \\
\hline
\end{tabular}

Source: Results of The Simple and Multiple Linear Regression, processed, 2014

of 1500 . Thus the average value of solidarity variable is 4.01, when compared to the range of the score $1-5$, then the results obtained is in the high category, it shows that the average of workers' solidarity is good

The variable of workers' job dissatisfaction is influenced by three indicators, namely: (1) the form of workers' job dissatisfaction with the indicator average of 3.89; (2) Problems That Are the Source of Workers' Job Dissatisfaction with the indicator average of 3,90 and (3) How to Deliver Wor- kers' Job Dissatisfaction with the indicator average of 3,77. The average of all indicators is 3.86 with a total score of 5784 and total frequency of 1500 . The Average score of workers' job dissatisfaction variable is 3.86 , when compared to the range of sore 1-5, then the results obtained is in high category, it shows that the average score of worker's job dissatisfaction is good.

Table 4 shows the results of the study: (1) normative demands have a significant effect on workers' job dissatisfaction; (2) soli- 
darity has a significant effect on workers' job dissatisfaction; (3) normative demands and solidarity together have a significant effect on workers' job dissatisfaction.

\section{The Influence of Normative Demands on Workers' Dissatisfaction}

Simanjuntak (2009, p.103) defines normative demands as the condition that workers' welfare will be fulfilled if workers get a decent income accompanied by social security, so that workers can meet the needs of life, increase work productivity and purchasing power of the community will also increase.

The influence of normative demands on workers' job dissatisfaction in this study is significant which can be seen in Table 4 . The significance was seen from the correlation coefficient $(\mathrm{r})$ of 0.493 which lies at a fairly strong interval and the determination coefficient(R square) of 0.153 . It means that there is a fairly strong linear relationship between the variables of normative demands with workers' job dissatisfaction. Normative demands give effect of $15.3 \%$ on workers' job dissatisfaction. While the remaining $84.7 \%$ is influenced by other variables that are not observed in this research. Besides, the constant value of workers' job dissatisfaction is 47.718; the variable of normative demands has negative influences on workers' job dissatisfaction variable of -0.240. Thus, if the level of normative demands is increased to a maximum, in this case the value is 1 , the dissatisfaction of the labor will be reduced by 47.718 .

The result of the research shows that if normative demands (city minimum wage, leave status, social security of labor and termination of employment) are not fulfilled by the employer, the worker's dissatisfaction (forms of workers' job dissatisfaction, problems that are the source of workers' job dissatisfaction, how to deliver workers' job dissatisfaction) will increase. The results of the study are in line with the results of Magdalena (2013) stating that if normative demands can be fulfilled it will contribute to the high job satisfaction.

\section{The Influence of Solidarity on Work- ers' Job Dissatisfaction}

Salim (1991, p.1451) explains that solidarity is an attitude of solidarity, a sense of destiny and togetherness which is basically a spirit of caring someone, a group or society over the fate of others. Furthermore, Ratri (2008) explains that labor participation in fighting for their welfare should be done in various ways including demonstration, with solidarity factor among workers, in order to put pressure on policy makers regarding labor.

The influence of solidarity on workers' job dissatisfaction in this study indicates that the correlation coefficient ( $r$ ) or the level of closeness of the relationship between the variables of solidarity with worker dissatisfaction is 0.524 . The $r$ value of 0.524 lies at a strong interval (0.50-0.75). While the coefficient of determination ( $R$ square) of 0.280 means that there is a strong linear relationship between solidarity variables with workers' job dissatisfaction, meaning that solidarity gives $28 \%$ influence on workers' job dissatisfaction. While the rest $72 \%$ is the influence of other variables that is not observed. The constant value of the variable of workers' job dissatisfaction amounted to 41.214 meaning that if the solidarity of workers is stronger to the maximum in this case the value is 1 , the employee's dissatisfaction will increase by 41.214 .

Labor solidarity through the support of the strong trade union's role in fighting for labor rights can affect workers' job dissatisfaction. Therefore, companies should prioritize the welfare of workers and more concern on the factors or sources of problems that cause workers' dissatisfaction. One of the ways is by giving workers rights in accordance with collective labor agreements and ensuring workers can work quietly and focus on their work. This becomes important to reduce the feeling of dissatisfaction of labor because workers will calmly work if the rights are met.

The results are in line with the results of Paskov \& Caroline Dewilde (2012) stating that solidarity is a willingness to contribute to the welfare of others. This is in accordan- 
ce with Beal's research results et al. (2014) showing that solidarity is a togetherness in terms of getting something fairly. Ingham \& Hilary Ingham (1998) in his research explains that since the 1980 , solidarity in Poland was more than just a union, but committed to economic and political reform. Furthermore, Kelly (2004) in his research explains that, to build a healthy global socioeconomic organization, it is needed a support that can direct the principle of solidarity and subsidiarity. Because according to the results of Jager's research, et al. (2013), solidarity experience is very important in supporting a career.

Thus, solidarity has a significant influence on workers' job dissatisfaction. If workers become more solid, they will be more daring to express their dissatisfaction in the form of protests.

\section{The Influence of Normative Demands and Solidarity on Workers' Job Dissat- isfaction}

The theory of Herzberg's dissatisfaction, 1966 (Teck Hong \& Amna Waheed 2011) assumes two sets of needs, namely concerning satisfaction and job dissatisfaction. Job satisfaction is the primary motivator associated with self-employment. Dissatisfaction is concerned with satisfying members of the organization and keeping them in the organization and it is related to the environment.

The results showed that normative demands and solidarity together affect the worker's dissatisfaction and showed a positive relationship of the normative and solidarity variables to the dissatisfaction of labor. The value of correlation coefficient is 0.427 meaning that the correlation or the level of relationship between normative demands and workers 'solidarity with workers' dissatisfaction is strong enough. Normative demands variable of -0.202 negatively affect the dissatisfaction of labor, if normative demands are fullfiled more, dissatisfaction will be reduced. The solidarity variable of 0.331 gives a positive influence on the dissatisfaction of labor. Therefore, if workers become more solid, they will be more daring to express their dissatisfaction in the form of protests. The coefficient of determination ( $\mathrm{R}$ square) is 0.380 , meaning that normative demands and solidarity give $38 \%$ influence on workers' dissatisfaction, the remaining $62 \%$ is determined by other variables that are not observed. While the value of $F$ arithmetic equals to 10.625> from $\mathrm{F}$ table 3.0902 shows that together, variables of normative and solidarity demands have significant effect on variable of labor dissatisfaction.

Thus the results of the study show that normative demands and solidarity together affect workers' job dissatisfaction. This means that if the normative demands are perceived good by the company, it will lead to low dissatisfaction of labor. The results of research also states that solidarity affects the dissatisfaction of labor so that all things that affect the solidarity among workers must be met both from normative demands and other workers rights related to a sense of solidarity among workers.

Utilizing the Maslow Hierarchy of Needs approach (1943), the factors that can affect the motivation and productivity of workers are as follows: (1) physical needs (wages, homes, clothing); (2) the need for security (position, career certainty, clear working status); (3) the need for social/ compassion relations (interpersonal relationships among colleagues, superiors and subordinates, and working climate); (4) the need for recognition/appreciation (corporate's appreciation for the individual for the performance, granting autonomy); (5) self-actualization needs (opportunities to develop creativity and self-realization/ professionalism). Thus, if the basic/physical needs of the workers are still not fulfilled even from the standard of decent living needs both physically, non-physically and socially then the turmoil and conflicts in industrial relations will certainly still take place in the future.

The result of the research shows the indicator of city minimum wage on normative demands variable, the respondent assess the amount of wages received is still not in accordance with the provisions of the regional minimum wage set by the government. 
In addition, the delay in wage payments and wage inequalities received with other workers are not in accordance with the prevailing policies. This is in line with Simamora's (1997, p. 139) opinion, if workers are not satisfied with their wages, they are likely to participate in unions for improving their living standards.

Labor participation in fighting for their welfare should be done in various ways including demonstrations, with solidarity among workers in order to put pressure on policy makers regarding labor. This is in line with Durkheim's (1893) thought that social solidarity is an inter-group relationship based on moral feelings and beliefs shared and reinforced by shared emotional experiences, that is, the incompatibility of wages given by the company, the right to leave, social security of labor and the policy of arbitrary termination of employment.

\section{CONCLUSION}

Based on the discussion, it can be drawn the following conclusions: (1) normative demands have a strong influence, meaning that city minimum wages, workers' leave, workers' social security and dismissal policy is appropriate. Normative demands become benchmarks, if the normative demands are fulfilled by the company, it will reduce workers' job dissatisfaction. (2) solidarity has a strong influence, meaning caring, giving each other and willingness to sacrifice among the workers is good. (3) normative demands and solidarity have a strong influence on labor dissatisfaction. Normative demands which are good and in accordance with existing provisions in collective labor agreements and solidarity between workers will reduce the dissatisfaction of labor.

\section{REFERENCES}

Beal, et al. 2014. Solidarity within a fixed community. Economics Letters. 125, pp.440-443.

Biezenski, R., 1996. The Struggle for solidarity $1980-$ 1981: Two waves of leadership in conflict. Europe-Asia Studies, 48(2), pp.261-284.

Chan, C.K.C., Ngai, P., \& Chan, J., 2010. The role of the state, labour policy and migrant workers' struggles in globalized China. In Globalization and Labour in China and India, pp. 45-63. Palgrave Macmillan UK.

Collins, N., 2011. Vietnam's labour relations and the global financial crisis. Research $\mathcal{E}$ Practice in Human Resource Management, 19(2), p.1.

Collins, N., Nankervis, A., Sitalaksmi, S., \& Warner, M., 2011. Labour-management relationships in transitional economies: convergence or divergence in Vietnam and Indonesia?. Asia Pacific Business Review, 17(3), pp.361-377.

Collins, N., Sitalaksmi, S., \& Lansbury, R., 2013. Transforming employment relations in Vietnam and Indonesia: case studies of state-owned enterprises. Asia Pacific Journal of Human Resources, 51(2), pp.131-151.

Departemen Tenaga Kerja dan Transmigrasi, 2013

Durkheim, E., 1893. The Division Of Labor In Society. The Free Press, New York.

Faber, S.H., 1990. The decline of unionization in the united State: What can Be Learned from Recent Experience. Journal of Labor Economics, 8(1), pp.S75-S105.

Ford, M., 2013. Violent industrial protest in Indonesia: Cultural phenomenon or legacy of an authoritarian past?. In New Forms and Expressions of Conflict at Work, pp.171-19o.

Hogg, M.A. \& Abrams, D., 1990. Social Identification: a Social Psychology of Intergroup and Grup Process. Routhledge, New York, USA.

Ingham, M. \& Hilary I., 1998. On The Solidarity of The Union Membership Decision in Poland. International Journal of Manpower, 19(Iss 1/2), pp.15-30.

Jager, et al. 2013. Experience of Solidarity:Why Executive Directors Work for Market Driven Nonprofits, Nonprofit and Voluntary Sector Quarterly, originally published on line 17 September 2012 version of record October.

Jiang, et al. 2009. An Analysis of Job Dissatisfaction and Turnover to Reduce Global Supply Chain Risk: Evidence From China. Journal of Operations Management. 27, pp.169-184.

Juliawan, B.H., 2011. Street-level politics: Labour protests in post-authoritarian Indonesia. Journal of Contemporary Asia, 41(3), pp.349-370.

Kelly, J.E., Solidarity and subsidiarity. 2004. "Organizing Principles" for Corporate Moral Leadership in The New Global Economy. Journal of Business Ethic. 52, pp.283-295.

Kurbetti et al. 2014. Industrial Relation at Cummins India Limited-A Case Study. Procedia Economics and Finance, 11, pp.86-89.

Lawang, R.M.Z., 1994. Kapital Sosial dalam Perspektif Sosiologik Suatu Pengantar. Fisip UI Press, Jakarta.

Le Queux, S., 2011. Industrial Democracy, Partnership and Decent Work in Response to the Global Financial Crisis-7th Asian Congress of the International Labour and Employment Relations Association, 20-23 September 2010. Transfer: European Review of Labour and Research, 17(1), 
pp.127-129.

Magdalena, S. et al. 2013. Implications of The Relation Between The Occupational Demands and Behavioural Reactions in The Romanian Academic Environment. Procedia-Social and Behavioral Sciences. 84, pp.1376-1380.

Maslow, A.H., 1943. A Theory of Human Motivation. Psycologi Review, 5o, pp.370-396.

Okafor, O.C., 2007. The precarious place of labour rights and movements in Nigeria's dual economic and political transition, 19992005. Journal of African Law, 51(1), pp.68-94.

Oshagbemi, T., 1997. Job Satisfaction and Dissatisfaction in Higher Education, Education+Training, 39(9), pp.354-359.

Paskov, M. \& Caroline D., 2012. Income Inequality and Solidarity in Europe. Research in Social Stratification and Mobility. 30, pp.415-432.

Ratri, V., 2008. Partisipasi Buruh dalam Aksi Unjuk Rasa. Jurnal Transdisiplin Sosiologi, Komunikasi dan Ekologi Manusia , 2, pp.321 - 336.

Salim, P. dan Salim, Y. 1991. Kamus Bahasa Indonesia Kontemporer. Modern English Press, Jakarta.

Sammut, G. \& Alex G., 2011. Cultural Encounters and Social Solidarity., Paper on Social Representations. 20, pp.1-17.

Sanders, K. \& Birgit S., 2006. Leadership and Solidarity behavior : Consensus in Perception of Employees within team, Personel Review, 35(5).

Sarfraz, A., et al. 2010. Insecure Job and Low Pay leads to Job Dissatisfication. Interdiciplinary. Journal of Contemporary Research In Business. 1(11), pp.90-102.

Sarkar, S., 2012. Determinants of employees' attitudes toward union membership in India. Journal of World Business. 47, pp.240-250.

Setyawan, H. \& Affandi. 2017. Strategi Perjuangan Serikat Buruh Dalam Tuntutan Kenaikan Upah di Kabupaten Jombang. 5(3), pp.1-11.

Simamora, H., 1999. Manajemen Sumber Daya Manusia. Edisi kedua. Cetakan kedua. STIE YKPN, Jogyakarta.

Simanjuntak, PJ., 2009. Manajemen Hubungan In- dustrial. Edisi: Kedua. Jala Permata Aksara, Jakarta.

Stuart A. et al. 1984. Academy of Management Journal, 27(3), pp.576-590.

Sutopo, O.R., 2013. Faktor Struktural dan Kultural Penyebab Kesenjangan Sosial: Kasus Industri Batik Pamekasan Madura. Jurnal Komunitas. 5(2), pp.230-239.

Teck H, T. \& Amna W., 2011. Herzberg's MotivationHygien Theory and Job Satisfaction in The Malaysian Retail Sector: The Mediating Effect of Love of Money, Sunway University, School of Business. 5, Jalan Universiti, Bandar Sunway 46150 Petaling Jaya, Selangor Malaysia. Asian Academy of Manajemen Journal, 16(1), pp.7394

Thomas, A.V., \& Sudhakumar, J., 2012. Perception of Site Engineers and Supervisors on Factors Influencing Construction Labour Productivity. In Proceedings of International Conference on Advances in Architecture and Civil Engineering (AARCV 2012), 21, p.953.

Thomas, A.V., \& Sudhakumar, J., 2014. Factors influencing construction labour productivity: an Indian case study. Journal of Construction in Developing Countries, 19(1), p.53.

Tiberius, V. \& Hall, A., 2010. The Journal of Positive Psychology, 5(3).

Tinley, L.M.I., 2014. Social capital development in a rural women's micro-enterprise in Mexico: Insights on leadership, trust and coorperation, Community development in a rural women's micro-enterprise in Mexico:insight on leadership, trust and coorperation. Community Development Journal Advance Access Published, July, 1-15.

Tyagita, A., 2011. Prinsip Kebebasan Berserikat Dalam Serikat Buruh Sebagai Upaya Perlindungan dan Penegakan Hak Normatif Pekerja, 26(1), pp.1-16.

Undang-Undang tentang Tenaga Kerja Nomer 13 tahun 2000.

Vangel, K., 2011. Schimidt Labor Research Center Semi- 